\title{
Centennial to Multi-Decadal Morphology Change and Sediment Budget Alteration with Consideration of the Impacts of the 2011 Tohoku Earthquake Tsunami along the Nobiru Coast, Japan
}

\author{
Nguyen Trong Hiep *(D), Hitoshi Tanaka (D) and Nguyen Xuan Tinh (D) \\ Department of Civil Engineering, Tohoku University, 6-6-06 Aoba, Sendai 980-8579, Japan; \\ hitoshi.tanaka.b7@tohoku.ac.jp (H.T.); nguyen.xuan.tinh.c5@tohoku.ac.jp (N.X.T.) \\ * Correspondence: nguyen.hiep.trong.p5@dc.tohoku.ac.jp
}

check for updates

Citation: Hiep, N.T.; Tanaka, H.; Tinh, N.X. Centennial to Multi-Decadal Morphology Change and Sediment Budget Alteration with Consideration of the Impacts of the 2011 Tohoku Earthquake Tsunami along the Nobiru Coast, Japan. J. Mar Sci. Eng. 2021, 9, 265.

http://doi.org/10.3390/jmse9030265

Academic Editor: Rodger Tomlinson

Received: 18 January 2021

Accepted: 24 February 2021

Published: 2 March 2021

Publisher's Note: MDPI stays neutral with regard to jurisdictional claims in published maps and institutional affiliations.

Copyright: (c) 2021 by the authors. Licensee MDPI, Basel, Switzerland. This article is an open access article distributed under the terms and conditions of the Creative Commons Attribution (CC BY) license (https:// creativecommons.org/licenses/by/ $4.0 /)$.

\begin{abstract}
The Nobiru Coast is situated on the southwest of the Ishinomaki Bay. The 2011 Great East Japan Tsunami severely devastated the Nobiru Coast and the adjacent Naruse River mouth. In this study, an investigation was conducted based on the available historic maps and images combined with in situ surveys that revealed the century-to-decade morphology change and sediment budget alteration in the Nobiru Coast. During the past two centuries, the longshore transport on the northeast coast and sediment supply from the Naruse River were the principal sediment supply onto the Nobiru Coast and the estimated annual net sediment input into the coast was $87,000 \mathrm{~m}^{3} / \mathrm{y}$. Until several decades ago, the construction of the Ishinomaki Port and the erosion preventing constructions (breakwaters, headlands) along the Ohmagari Coast on the northeast areas caused a dramatic reduction of longshore transport to the Nobiru Coast. Hence, the net sediment input fell to $46,000 \mathrm{~m}^{3} / \mathrm{y}$. After the tsunami, the sediment input was further reduced to $29,000 \mathrm{~m}^{3} / \mathrm{y}$ and this loss was closely related to the intruded sediment into the Naruse River. The outcomes of this study are highly valuable for the government authorities to manage the long-term coastal and riverine morphological changes after the 2011 tsunami.
\end{abstract}

Keywords: sediment budget; 2011 Tohoku earthquake and tsunami; depth of closure; sediment intrusion

\section{Introduction}

The 2011 Great East Japan Earthquake occurred at 14:46 (Japan standard time) on 11 March 2011, generating gigantic tsunami waves approaching the east of Japan. The tsunami waves with a maximum height of $40 \mathrm{~m}$ attacked the coastal areas from Iwate to Fukushima Prefecture. The disaster was considered one of the largest catastrophes in Japan for many recent decades and caused huge irreversible casualties and damages to people and infrastructure along the coast.

Regarding tsunami-induced inland damages, inundation on which the tsunami propagates further inland was the reason for infrastructure damages and human losses [1-4]. In addition, studies of large-scale coastal and estuarine morphology change, both onshore and offshore, induced by tsunamis have been widely explored. Takahashi et al. [5] conducted one of the very first studies using numerical modeling and experimentation to quantify the actual-case tsunami impact on coastal sediments after the 1960 Chilean Tsunami. Since then, many post-tsunami surveys mostly after two recent giant tsunamis in the early 21st century - the 2004 Great Indian Ocean Tsunami and the 2011 Great East Japan Tsunami-have been carried out to identify and examine the morphology damages.

In relation to the 2004 Great Indian Ocean Tsunami, much research has been conducted [6-9]; however, these studies revealed the limited correlation with post-event morphology due to the lack of field observation data such as morphology surveillance and 
sediment movement either before or after the tsunami. Since the 2011 Great East Japan Tsunami, more thorough analyses and examinations have been performed to analyze the severe erosion on coasts and complex estuarine morphology phenomena with adequate field measurement, aerial photographs, and satellite images before and after the tsunami event [10-14]. Among them, Tanaka et al. [10] reported comprehensively either on the overall significant changes of the coastal and estuarine areas in Miyagi Prefecture such as beach erosion, breaching, sand barriers, and disappearance of sand spits, or stressed the impacts of tsunami waves, especially the tsunami return flow on the estuaries.

The tsunami-induced impact on coastal and estuarine morphology can be classified from temporary deposition and erosion to permanent modifications of coastal landform. Therefore, the recovery of morphology is a vital factor in assessing any tsunami impact and it requires continuous field observations from years to decades. Choowong et al. [15] and Koiwa et al. [16] conducted some of very few studies discussing the morphology recovery of beach and barrier spits at the estuaries after the 2004 Indian Ocean Tsunami. In Japan, more studies from local to regional scales related to the recovery process after the 2011 Great East Japan Tsunami have been carried out [17-20]. However, due to the importance of river management concerning future flood control planning, many researchers prioritized the recovery in the mouth of rivers as compared to sandy beaches and coastal recovery.

This study focuses on the morphology change of the Nobiru Coast in Miyagi Prefecture. The instant post-morphology change was investigated by Adityawan et al. [14] using pre- and post-bathymetries along with the status quo snapshot immediately after the tsunami arrival. Nonetheless, because the Nobiru Coast is an important region connecting between the two most crucial bays in Miyagi Prefecture, the understanding of long-term morphology change in this area is essential. In this study, the historical maps and landscape images (aerial and satellite), as well as past in situ beach surveys were collected to carry out the morphology investigation and estimate the annual net sediment supply into the Nobiru Coast. In addition, the relationship with the adjacent Naruse River mouth after the 2011 tsunami was also considered since this area was the most damaged area along the Ishinomaki Bay [14]. As a result, the centennial to decadal sediment budgets in the Nobiru Coast were estimated. The outcome of this study will be highly valuable for the government authorities with regard to the decision making of long-term coastal and riverine management in this area after the 2011 tsunami.

\section{Background}

\subsection{Study Area}

The Nobiru Coast is situated on the southwest of the Ishinomaki Bay and northeast of the Matsushima Bay in Miyagi Prefecture, Japan (Figure 1). The coast has a length of about $2.8 \mathrm{~km}$ extending from the Naruse River mouth to Miyato Island. The Katsugigaura Channel is in between the Nobiru Coast and Miyato Island as the path for sea water exchange in and out of the Matsushima Bay. Adjacent to the Nobiru Coast in the north direction is the Naruse River mouth. The Naruse River is a class A river where the water resources and environmental management, as well as disaster control and protections against natural extreme disasters are managed by the national government. The Naruse River has a length of $89 \mathrm{~km}$ and a catchment area of $1133 \mathrm{~km}^{2}$. 


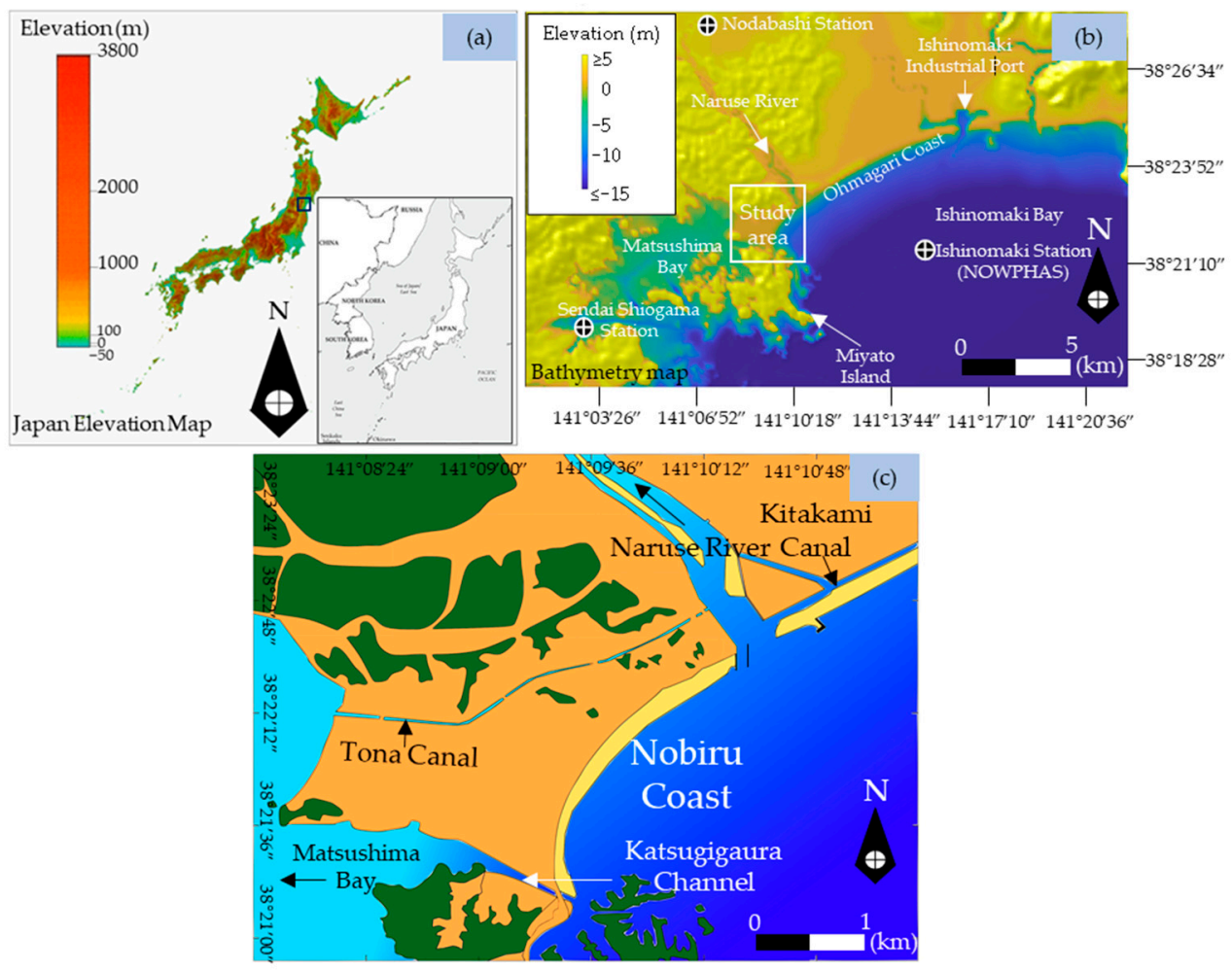

Figure 1. Map of study area. (a) Map of Japan. (b) Bathymetry of Matsushima Bay and Ishinomaki Bay. (c) Location of the Nobiru Coast.

Figure 2 shows the 2-h interval wave data (NOWPHAS, the Nationwide Ocean Wave Information Network for Ports and Harbours) observed from 2011 to 2018 at Ishinomaki Station (Figure 1b). The dominance of southeast (SE) and south-southeast (SSE) wave directions in the Ishinomaki Bay indicates the main direction of alongshore drift is from the Ohmagari Coast towards the Nobiru Coast. Since the longshore sediment input to the Nobiru Coast is downdrift of the longshore transport in the Ishinomaki Bay, the sediment potential to the coast has a close relationship with the morphology of the northeast area.
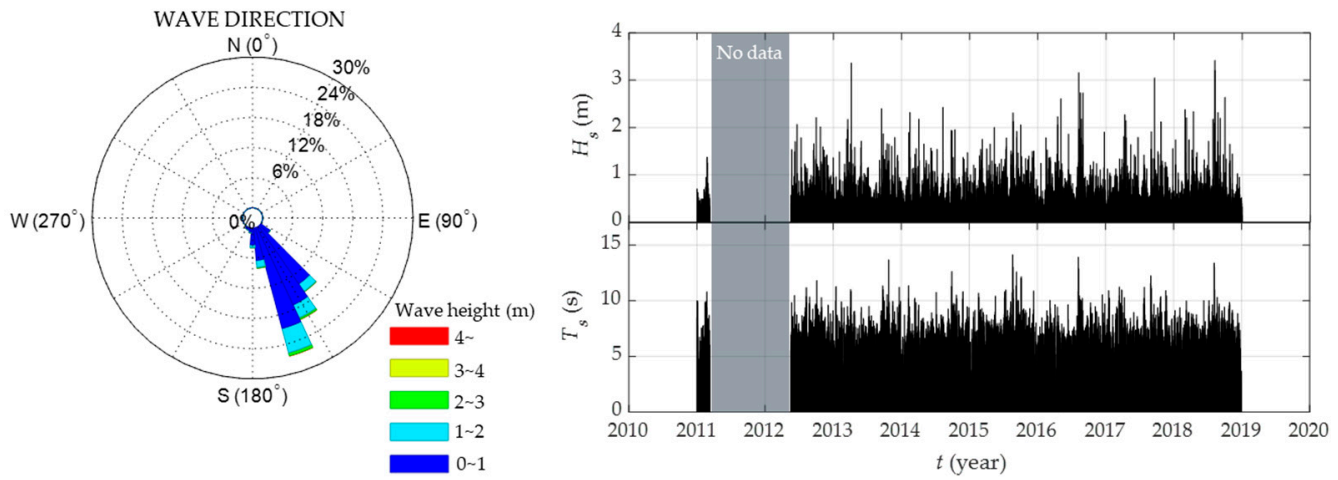

Figure 2. Wave direction, wave height $\left(H_{S}\right)$, and wave periods $\left(T_{S}\right)$ measured at Ishinomaki Station (NOWPHAS) $8 \mathrm{~km}$ offshore from the Nobiru Coast.

After the first phase of the construction of the Ishinomaki Industrial Port was almost completed in 1975, severe erosion occurred along the Ohmagari Coast, forcing the Miyagi Government Prefecture to implement the responsive countermeasure of detached breakwaters and headlands in 1982, as shown in Figure 3. These structures caused a series of sediment obstruction, inducing the reduction of longshore sediment input to the Nobiru Coast. Inoue et al. [21], by delineating the shorelines from historical maps and aerial pho- 
tos, calculated the potential of alongshore sediment supply to the Nobiru Coast before the appearance of breakwaters and headlands of about $60,000 \sim 70,000 \mathrm{~m}^{3} / \mathrm{y}$. Afterwards, Takahashi and Tanaka [22] applied Empirical Orthogonal Function (EOF) analysis on the in situ bathymetry data surveyed from 1990 to 2002 to extract the component of longshore sediment transport and estimate the longshore sediment transport rate along the Ohmagari Coast. The sediment rate after passing by the T-headland reduced from $74,000 \mathrm{~m}^{3} / \mathrm{y}$ to $23,000 \mathrm{~m}^{3} / \mathrm{y}$, demonstrating that the reduction of almost $70 \%$ of longshore sediment availability to the Nobiru Coast was induced by the placement of detached breakwaters and headlands.
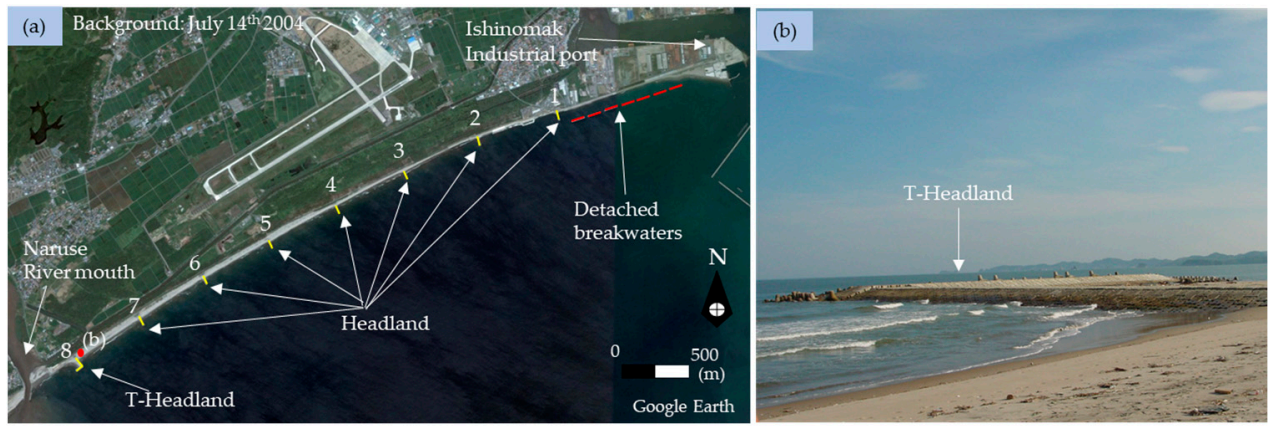

Figure 3. (a) Detached breakwaters and headlands along the Ohmagari Coast. (b) Closer view of the T-headland near the Naruse River mouth (Captured in 2014).

Along with the provision of sediment from the alongshore drift, the sediment discharge from the Naruse River also contributes to the sediment input into the Nobiru Coast [21,23]. By using the river bathymetries and measured tidal-free river discharges from Nodabashi Station in the upstream far from the mouth at about $18 \mathrm{~km}$, Inoue et al. [21] indicated that the increase of sediment discharge from the Naruse River closely correlated with the floods, with a discharge value over $700 \mathrm{~m}^{3} / \mathrm{s}$. The variation of the daily river discharge (1974 2017) measured from Nodabashi Station is shown in Figure 4. According to Sato et al. [24], the average sediment discharge of the Naruse River was roughly $24,000 \mathrm{~m}^{3} / \mathrm{y}$.

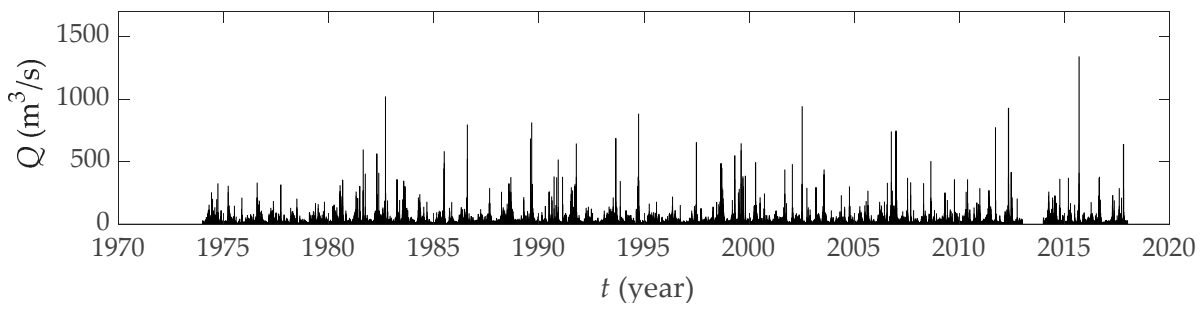

Figure 4. Daily river discharge at Nodabashi Station (1974 2017).

\subsection{Impacts of the 2011 Great East Earthquake and Tsunami}

The 2011 tsunami waves severely damaged the Nobiru Coast and the infrastructure in the inland area (Figure 5). According to Haraguchi and Iwamatsu [25], the tsunami height near the Nobiru Coast and inland area ranged from 5.04 to $8.16 \mathrm{~m}$, causing large-scale inundation (Figure 5a). In the Naruse River mouth, the maximum tsunami wave height at Nobiru Water Level Station was $6.96 \mathrm{~m}$ at 15:55 (Figure 5b) and the following waves were also very high until the next day. The tsunami waves intruded farther upstream until the Hataya Water Level Station far from the mouth at around $14 \mathrm{~km}$ [26-28]. Figure 5c,d shows the collapses near the entrance to the Tona Canal and the damage of the riprap structure along the south of the Nobiru Coast. Moreover, the tsunami waves washed away the entire sandspit attached to jetties in the mouth area of the Naruse River (Figure 5e,f). Such a 
wide-open river entrance has raised a concern over the sediment transport by waves in the river mouth area, which could potentially cause a substantial change in the Nobiru Coast.
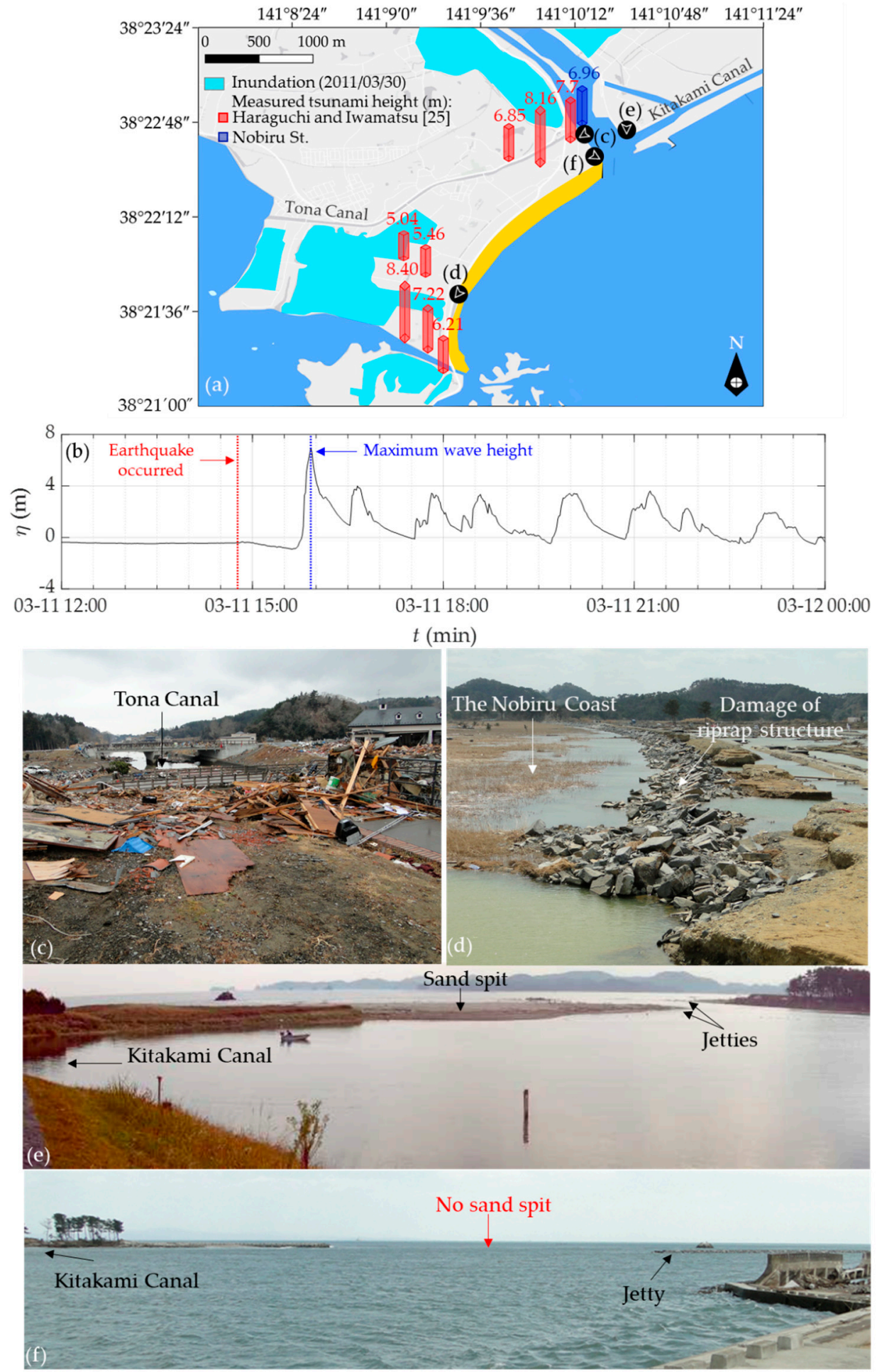

Figure 5. (a) Measured tsunami wave heights in the Nobiru Coast and Naruse River mouth (Datum: Tokyo Peil). (b) One-minute measured water level in Nobiru Station (Datum: Tokyo Peil). (c) Collapses of infrastructure in the Tona Canal (Captured: 18 April 2011). (d) Damage of coastal structure (Captured: 18 April 2011). (e) Existence of the sandspit before the 2011 tsunami (Captured: May 2002). (f) Disappearance of the sandspit after the 2011 tsunami (Captured: 18 April 2011). 


\section{Materials and Methods}

Analysis of morphology change of the Nobiru Coast was performed combining century-to-decade shoreline observation. Beach surveys along the coast were also taken over the period of about 10 years to evaluate the spatial depth limit of sediment transport. All spatial data and analyses were integrated into a designated reference system.

\subsection{Historical Shoreline-Change Analysis}

In the Nobiru Coast, five historical maps and their delineated shorelines from 1800 to 1950 were inherited from Tanaka et al. $[29,30]$. The initial map was created in Edo Period, while the rest were originally created in connection to the construction project of Nobiru Port designed by a Dutch civil engineer and started in 1878. However, the project was finally withdrawn due to the mistakes in design and site selection at the time [31]. The aerial photographs and satellite images from the Geospatial Information Authority of Japan (GSI) and Google Earth Database with a sufficiently high resolution (0.5 2.5 m) were retrieved, covering 56 years (1963 2019). In addition, the aerial photographs of the Naruse River mouth with high resolution $(\sim 0.5 \mathrm{~m})$ taken by the Kitakami-Karyu River Office, Ministry of Land, Infrastructure, Transport and Tourism (MLIT) were also collected. The detailed information of the utilized data set is presented in Figure 6a.

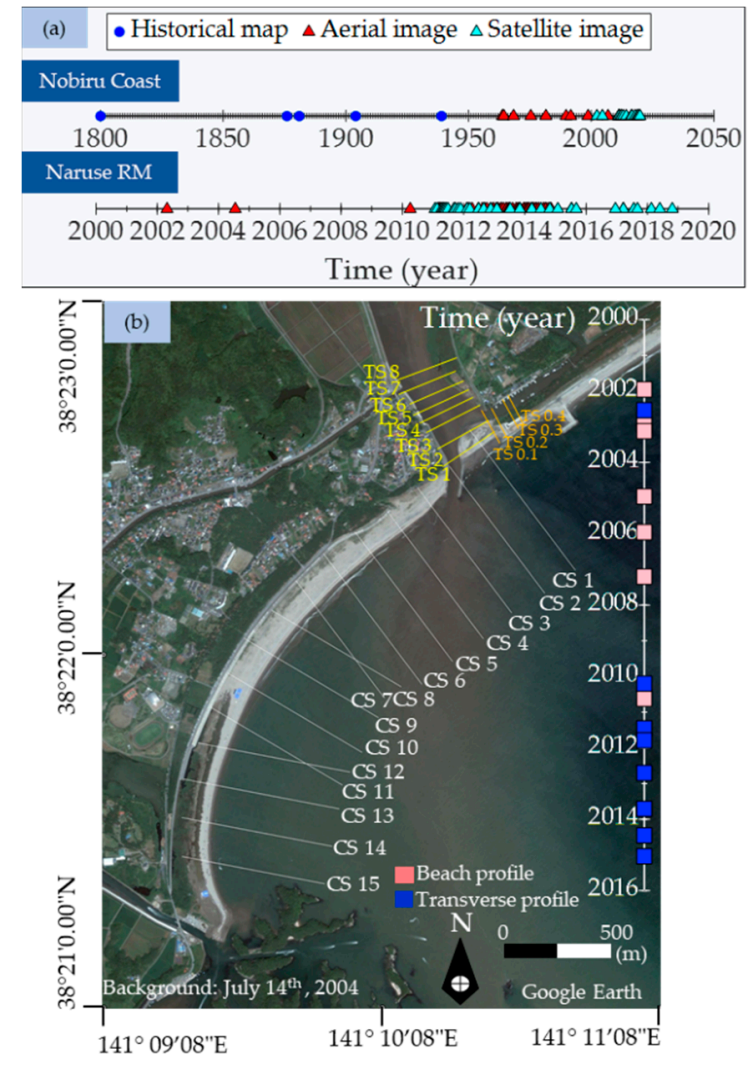

Figure 6. (a) Collected data set of historical map and images. (b) In situ profile surveys.

For each image, a series of ground control points (GCP) was selected and assigned to a spatial reference system, WGS84/UTM Zone 54S. All images were then geo-referenced and transformed into orthophoto images by utilizing a projective matrix as the image transformation method and bilinear interpolation as the image resampling method. The shoreline from each image is consistently defined as the wet-dry line or the high-water line (HWL), from which the division between the dark (wet) and light (dry) sand on the beach is extracted [32]. The K-means clustering algorithm based on the clustering technique was applied to classify the wet and dry sand areas into two different groups (clusters). A detailed description of this cluster analysis is beyond the scope of this paper and referred 
to in [33-35]. Each image was divided into small block areas and the ones including both sea and land pixels were selected for the clustering process. A local threshold determined by Otsu [36] was selected for each block to extract the shoreline. The shorelines were then combined to represent a complete one for the image. A simple tidal correction was applied to reduce the inconsistency induced by the different levels of tide at image capturing time. Each shoreline was translated onshore or offshore along a cross-shore section using the beach slope of 0.08 and the corresponding estimated tidal level acquired from the Sendai Shiogama Station (Figure 1b). The accuracy of the detected shorelines was affected by a certain uncertainty derived from the geo-reference and image resolution. By considering all possible errors, a total accuracy rounded to $\pm 3 \mathrm{~m}$ was obtained for the detected shorelines.

In order to facilitate the later calculation, another reference system with a baseline rotated counterclockwise 211 degrees to the north was designated to reference all images and detected shorelines.

\subsection{Spatial Behavior of Depth of Closure along the Nobiru Coast}

The survey of beach profiles along the Nobiru Coast was conducted 7 times by the Miyagi Prefectural Government from 2001 to 2010 using an echosounder and integrated DGPS. A total of 15 beach profiles at a spacing of $250 \mathrm{~m}$ was measured. The measurements inside the Naruse River mouth after the 2011 tsunami (12 transverse profiles) provided by MLIT were also collected. The GPS Precision was $\pm 2 \mathrm{~m}$ and that of the echosounder was $0.2 \mathrm{~m}$. The measuring frequency was different for each profile. The measured data were synchronized with the designated reference system for the images. Figure $6 \mathrm{~b}$ shows the location of the measured profiles and the detailed measuring frequency.

The depth of closure, $D_{C}$ is a theoretical concept to partition off the shoreface into different morphodynamic regions. $D_{C}$ is commonly perceived as the transition from the upper shoreface to the lower shoreface $[37,38]$. Under the time and length scales of beach profile behavior illustrated by Stive et al. [39,40] and Stive and deVriend [41], the upper shoreface was well affected by surf zone processes while the lower shoreface was majorly affected by wave shoaling and upwelling/downwelling currents, of which the profile variation is insignificant (or within the uncertainty range) at timescales from years to decades. To calculate $D_{C}$ along the coast, the present study approached the direct method based on the field observation of beach profiles. The mean elevation and associated standard deviation of each profile was calculated and $D_{C}$ was defined the point in which the standard deviation fell to an acceptable uncertainty limit and the vertical variability was able to be considered negligible. The uncertainty of standard deviation was closely related to the accuracy of the field measurement together with the spatial and temporal scales of the field observation. In some past studies, for a beach morphology at a length scale of kilometers and a timescale of decades, the selected uncertainty of standard deviation was about $0.15 \sim 0.3 \mathrm{~m}[37,42,43]$. In this study, the beach profiles with at least 6 measuring times were selected and the prediction of $D_{C}$ was considered to satisfy the deviation of the beach profile less than the vertical measuring accuracy as of $0.2 \mathrm{~m}$.

\subsection{Sediment Budget}

In order to investigate the long-term sediment budget in the Nobiru Coast, 3 different temporal periods were divided based on the important events which were Period 1: Before the constructions of detached breakwaters and headlands; Period 2: Before the 2011 tsunami; and Period 3: After the 2011 tsunami. The sediment budget considers 2 major sediment supplies of the sediment discharge from the Naruse River and the longshore sediment transport from the Ohmagari Coast to make a comparison with the annual net sediment input in the Nobiru Coast (see Section 4.3). The longshore sediment transport passing through the T-headland from Takahashi and Tanaka [22] was inherited. Considering that the sediment input from the Naruse River depended on the frequency of flood events in conjunction with the morphology change of the river channel, the average annual sediment flux obtained from Sato et al. [24] could be utilized for all three periods. 


\section{Results and Discussion}

\subsection{Centennial to Multi-Decadal Morphology Change in the Nobiru Coast}

Figure 7 represents the shoreline behavior during three different temporal periods. About 2 centuries ago, the first observed shoreline in 1800 was located about $1.5 \mathrm{~km}$ onshore compared to the recent shoreline. During the 1800s, the sediment deposited significantly on the right side of the coast. It is interesting to realize the abnormal horn shape appearing on the left coast. These horn shape positions are referred to the landlocked islands. The locations of landlocked islands (Figure 7a; A,B,C) are now located farther inland and can be observed in closer view in Figure 8a. Given that these islands are unmovable, the sediment gradually deposited until it entirely covered the islands, as seen as the shoreline in 1939.

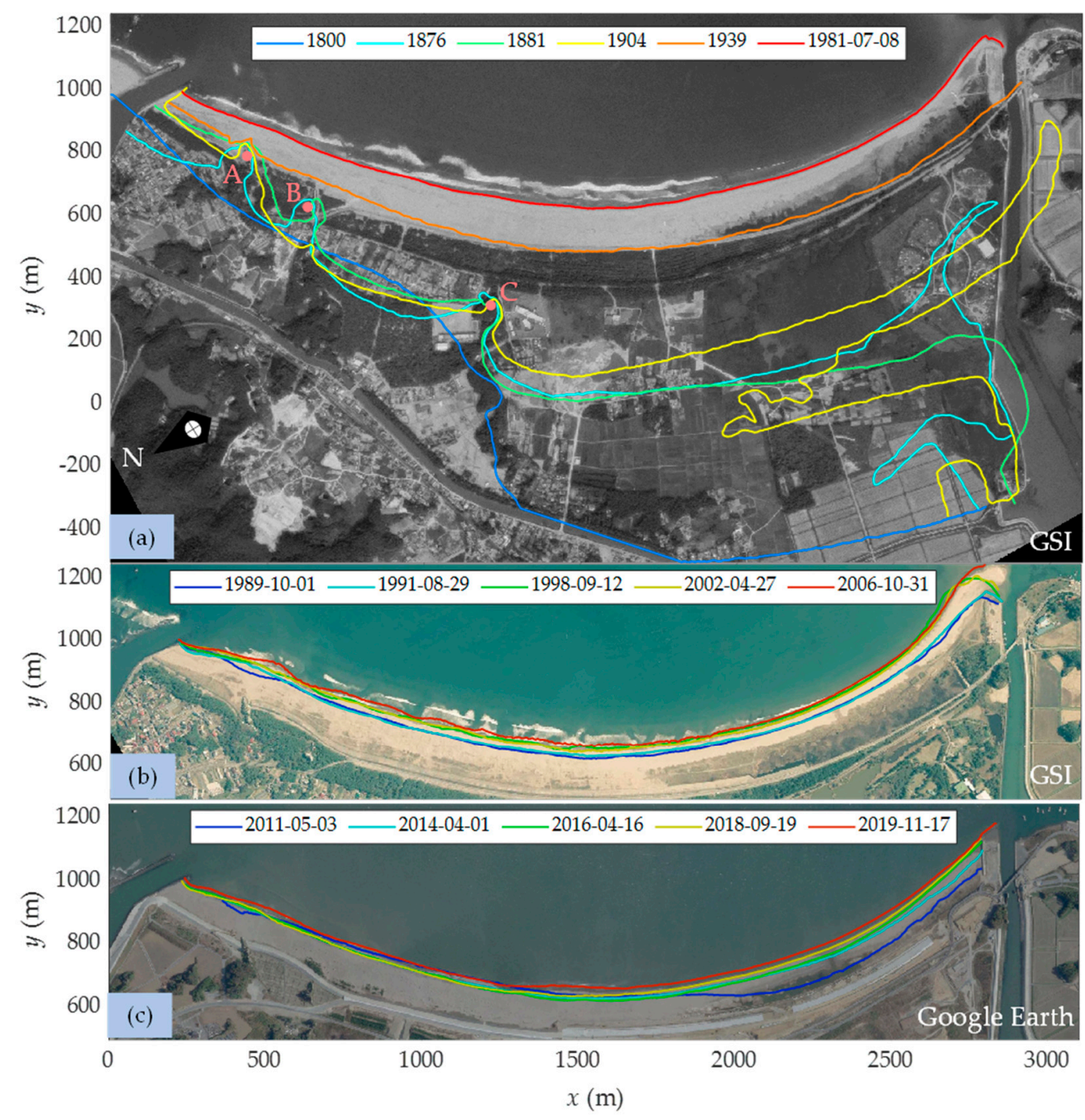

Figure 7. Historical shorelines (1800 2019). (a) Before the constructions of detached breakwaters and headlands. (b) Before the 2011 tsunami. (c) After the 2011 tsunami.

Figure $7 \mathrm{~b}$ shows the progressive evolution of the Nobiru Coast before the 2011 tsunami. Due to the reduction of alongshore sediment transport after the constructions of detached breakwaters and headlands in the Ohmagari Coast, the post-construction sediment deposit was not as excessive as that of the pre-construction period. Since the Miyato Island is located on the right end of the Nobiru Coast (based on this reference system) as the interruption of the longshore drift, the continuous sediment deposit caused the right end of the coast to attach to the Miyato Island (Figure 8b). 


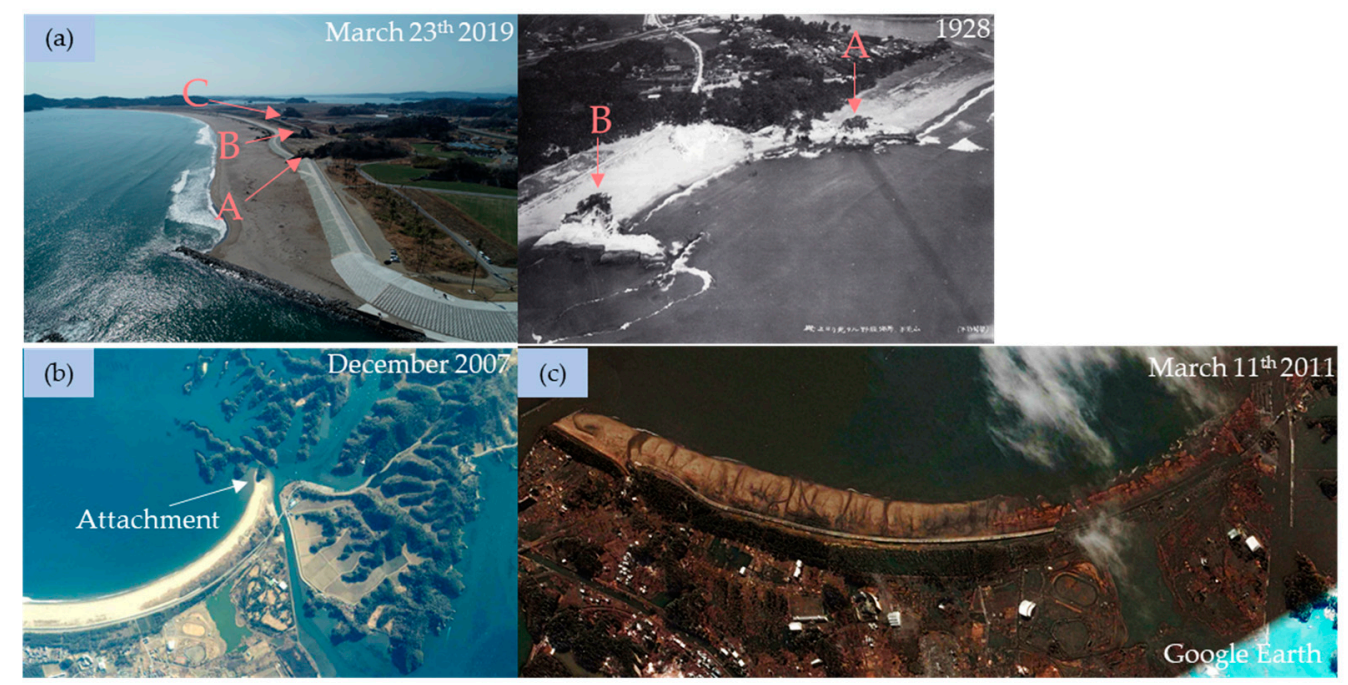

Figure 8. (a) Landlocked islands: left (UAV, Unmanned aerial vehicle), right [44]. (b) Severe deposition connecting to the Miyato Island (taken by Miyagi Prefectural Government). (c) Destruction of the Nobiru coast immediately after the tsunami.

After the 2011 tsunami, the morphology of the coast was completely changed (Figure 7c). The satellite image taken on the disaster day shows the massive destruction caused by the giant tsunami (Figure 8c). The right coast almost disappeared and in the inland area, the pine tree forest was washed away, and the inundation was still visible. According to Adityawan et al. [14], the difference in damage between the left and right coast is because of the difference of protection structures in the two regions. The left coast area was protected by a concrete embankment with 5-m height, while the right coast was only preserved by a riprap structure. Dao et al. [45] performed multiple numerical simulations of tsunami wave arrival to the coasts with different scenarios of the embankment height. The simulation results showed the evidence of coastal embankment significantly weakening the velocity magnitude of the tsunami wave on the shore region. Subsequently, during the recovery time, the sediment from the left coast was transported more to the right coast to compensate for the sediment loss. The recovery has continued until now.

\subsection{Spatial Offshore Limit of Bathymetry Change along the Nobiru Coast}

The behavior of representative beach profiles and their determination of the depth of closure are demonstrated in Figure 9. In all profiles, the foreshore and upper shoreface are clearly identified by higher standard deviation, reflecting the onshore transport of material due to velocity-skewed incoming waves and the offshore transport due to gravity. The variation of standard deviation towards the lower shoreface and inner shelf gets smaller and reaches a nearly constant value where $D_{C}$ can be determined. The beach profiles on the left coast $(\mathrm{CS} 2,5,7)$ have steeper shoreface compared to the profiles on the right coast $(\mathrm{CS} 9,13)$ and the value of $D_{C}$ also gradually decreased along the Nobiru Coast. This was a result of the topography near the Miyato Island on the south of the coast. As seen in Figure 1b, the Miyato Island has the characteristics as the wave obstruction in front of the right end of the Nobiru Coast and the area adjacent to the island is much shallower. Waves approaching in the dominant directions (Figure 2) and diverging due to refraction in the bay reach the right coast with a smaller wave height and energy in contrast to the left coast. This distinction can be observed by the noticeable swash zone and breakers on the left coast in the background images of Figure $7 \mathrm{a}, \mathrm{b}$. The spatial variability in $D_{C}$ along the Nobiru Coast is displayed in Figure 10 and the fitting function is expressed as follows:

$$
D_{C}=-3.0 \times 10^{-12} x^{3.5}+6.7(\mathrm{~m})
$$

where $x$ is the alongshore distance from the origin of the designated reference system. 


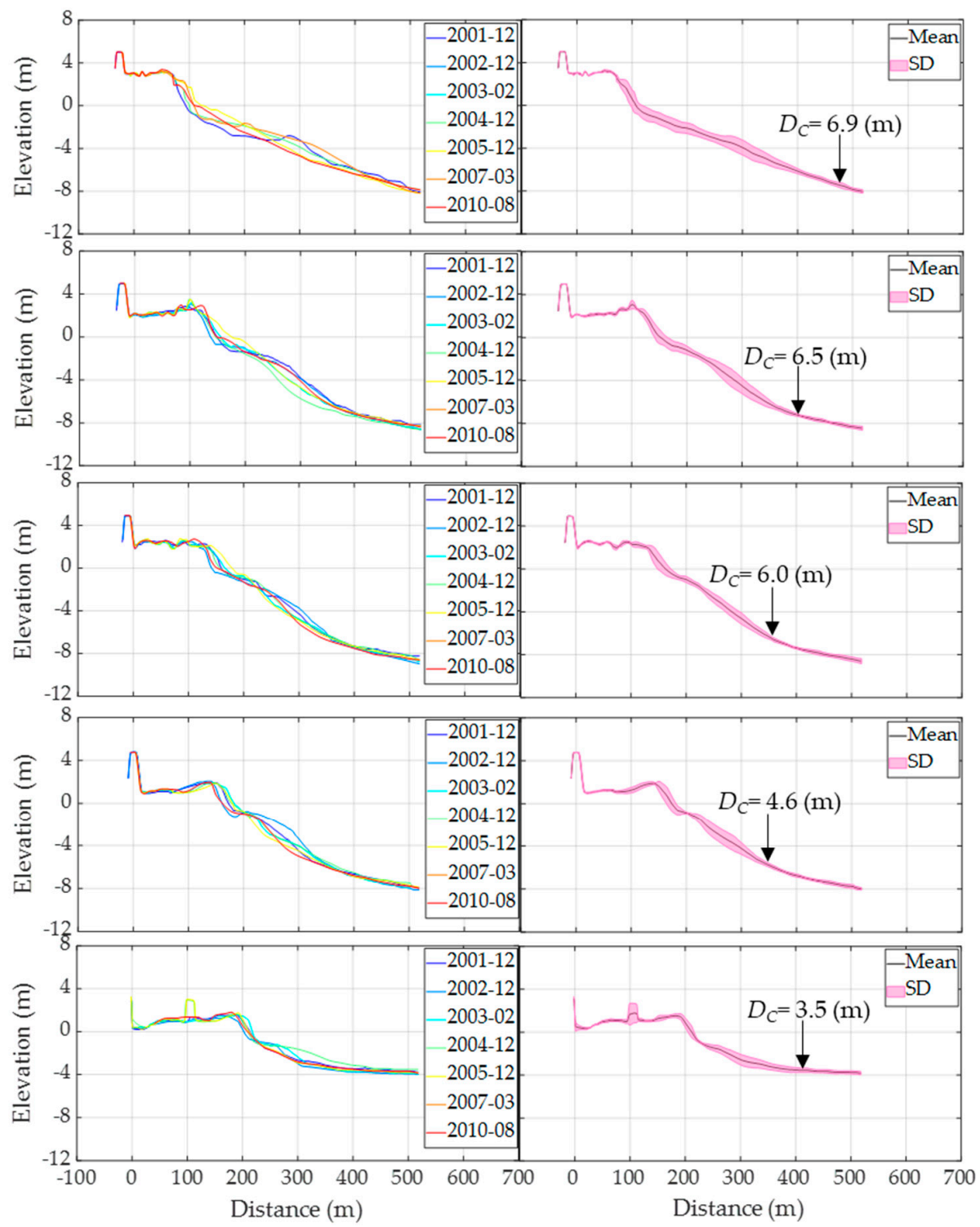

Figure 9. Selected beach profiles and determination of depth of closure. (Datum: Tokyo Peil).

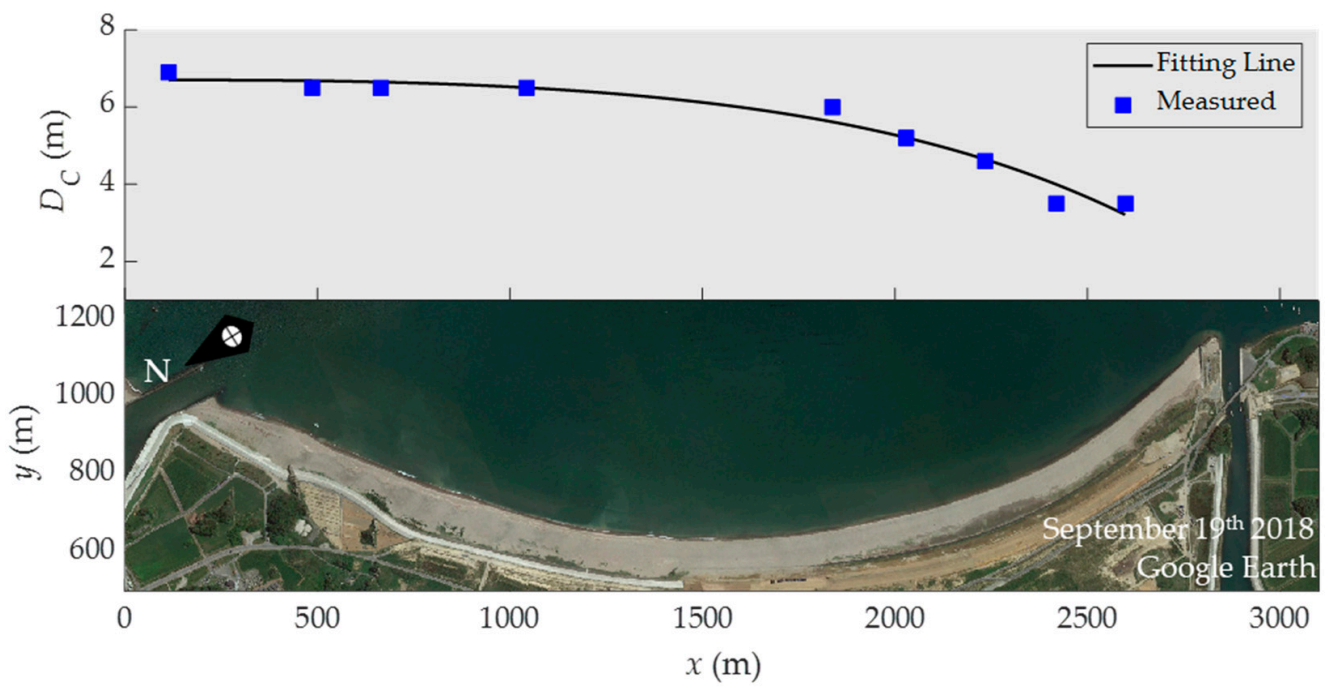

Figure 10. Depth of closure variation. 
Even though a number of studies has shown the alongshore variation of $D_{C}$ at different length scales in multiple study sites in the world $[37,42,43]$, the spatial behavior of $D_{C}$ in the Nobiru Coast has never been in any discussions in the past studies. In the Ishinomaki Bay, considering the wave base of storm and fair-weather waves are similar, the average value of $D_{C}(=8 \mathrm{~m})$ for the entire Ishinomaki Coast obtained by Uda [46] in 1990s was widely used in many past studies related to the coastal morphology changes and coastal planning strategies. However, the utilization of the fixed value of $D_{C}$ has been recently considered unsuitable after Widyaningtia et al. [47] proved that $D_{C}$ in some areas is much different from the value obtained by Uda [46], owing to the different topography, especially near the coastal ports. Even though the measured $D_{C}$ has a tendency to approach the value provided by Uda [46], the decrease of $D_{C}$ on nearly half of the Nobiru Coast requires the re-consideration for the sediment balance in this area.

\subsection{Annual Net Sediment Input and Reduction Due to the Disappearance of the Sandspit of the} Naruse River Mouth

It is common to calculate the volume change of sediment by the area of newly deposited sediment and the depth of active motion based on the theory of one-line model [48]. The sediment volumetric change of the Nobiru Coast, $V$, at different time can be expressed as:

$$
V(t)=\int_{A} \int\left\{D_{C}(x)+D_{B}(x)\right\} d A
$$

where $d A$ is the area change at each time step with the reference line as the first observed shoreline in 1800. The depth of active motion is the sum of $D_{C}$ and the berm height, $D_{B}$. $D_{C}$ along the coast is estimated by Equation (1), while $D_{B}$ is calculated from the empirical equation presented in Uda [46]:

$$
D_{B}(x)=0.32 \times D_{C}(x)
$$

The annual net sediment input is defined as the rate of the sediment volumetric change. There might be uncertainties of the volumetric change due to the transport between the lower shoreface and the inner shelf to the upper shoreface or historical rises in sea level. However, these uncertainties are usually difficult to consider accurately and require larger spatial (regional $>10^{4} \mathrm{~m}$ ) and temporal scales (century-to-millennium) [49]. Thus, the volumetric uncertainties in the estimate are calculated from the uncertainty of the beach profiles and detected shorelines.

The variation of sediment volumetric change in the Nobiru Coast is clustered into three main temporal scales. The first temporal scale is centennial while the others are decadal. The variation of sediment volumetric change in each period is shown in Figure 11. During Period 1 (1800 1975), the enormous increase of about $15 \times 10^{6} \mathrm{~m}^{3}$ in the sediment volume in the Nobiru Coast is observed. The annual net sediment input was $87,000 \pm 12,000 \mathrm{~m}^{3} / \mathrm{y}$. In Period 2 (1982 2006), after construction started in 1982, the sediment volumetric change stopped increasing excessively, leading the net sediment input being reduced by almost half to be approximately $46,000 \pm 3000 \mathrm{~m}^{3} / \mathrm{y}$. After the 2011 tsunami, the volumetric change returned to the value at the beginning of the second temporal period. Since then, the Nobiru Coast has recovered with less annual net sediment input, at about 29,000 $\pm 2000 \mathrm{~m}^{3} / \mathrm{y}$ in Period 3. The deficit before and after the tsunami was $17,000 \mathrm{~m}^{3} / \mathrm{y}$. 

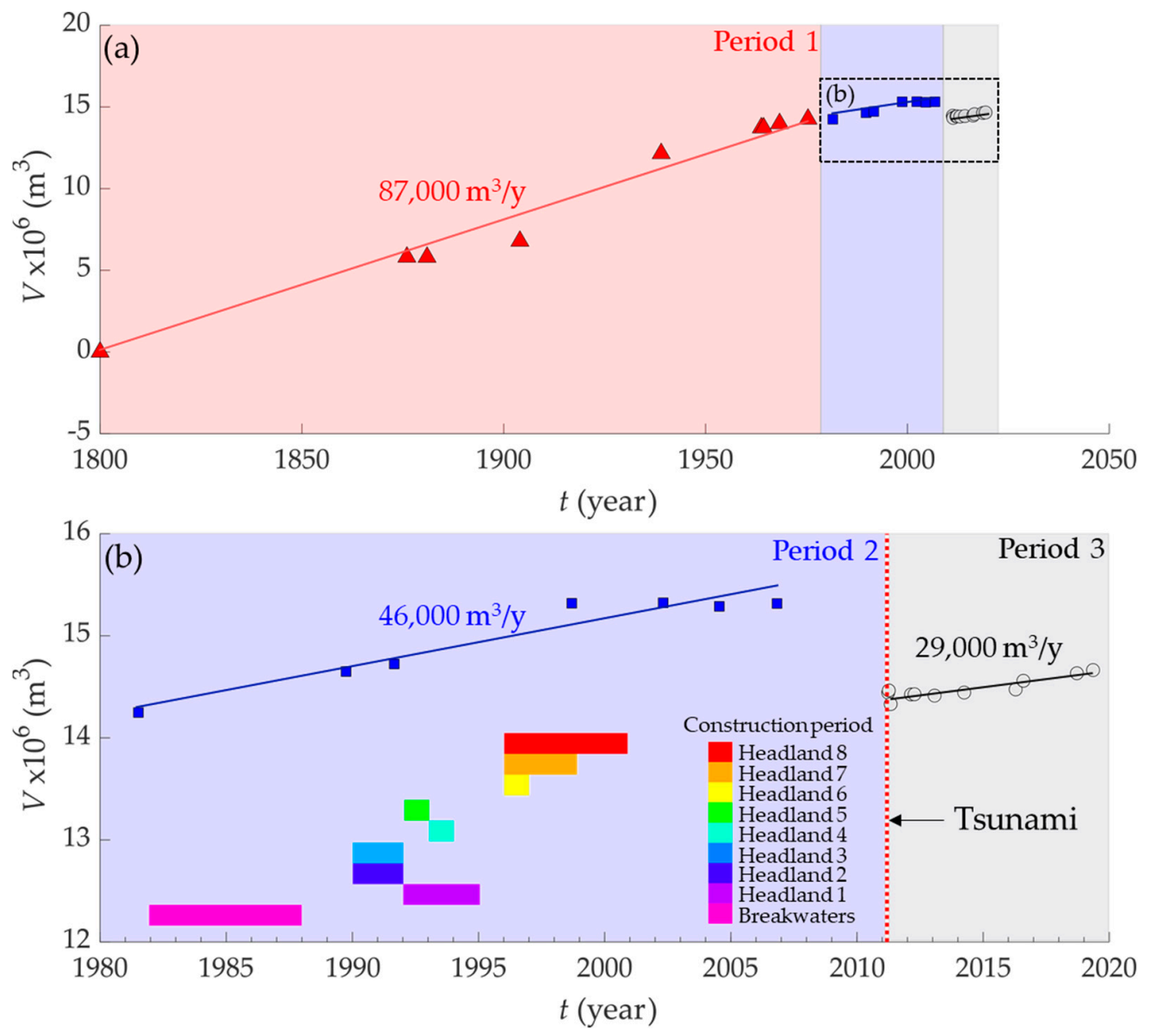

Figure 11. Sediment volumetric change and annual net sediment input to the Nobiru Coast. (a) Period 1. (b) Period 2 and Period 3.

As the reduction of longshore sediment transport from the Ohmagari Coast has been elucidated in many past studies [21-24], the construction of detached breakwaters and headlands has been responsible for the massive decrease in annual net sediment input to the Nobiru Coast. However, the deficit between the pre-and post-tsunami sediment input has not been speculated. This study suggests this deficit was induced by the sediment intrusion into the Naruse River mouth. Figure 12a,b shows the morphology pre-and posttsunami, as well as the devastation by the tsunami in the Naruse River mouth. Due to the disappearance of the sand spit, the mouth was wide open, resulting in waves that approached upstream furtherly and scoured the sediment near the left bank to transport upstream; therefore, the government had to implement a new concrete embankment to protect the left bank from erosion (Figure 12c). According to Hiep et al. [50], firstly, due to wave diffraction, the Kitakami Canal was filled by sediment, and until the entrance of canal was almost covered up, the sediment started depositing on the upstream land area (Figure 12d). Similar behavior of morphology change can be observed by the depth change in the river mouth (Figure 13). The increased rate of sand area from 2011 to 2018 was about $9000 \pm 1000 \mathrm{~m}^{2} / \mathrm{y}$ (Figure 14). After the 2011 tsunami, the newly deposited sediment thickness inside the river mouth was averagely $2 \mathrm{~m}$ (Figure 13). As a consequence, the volume of sediment transported into the river mouth was about 18,000 $\pm 2000 \mathrm{~m}^{3} / \mathrm{y}$. 


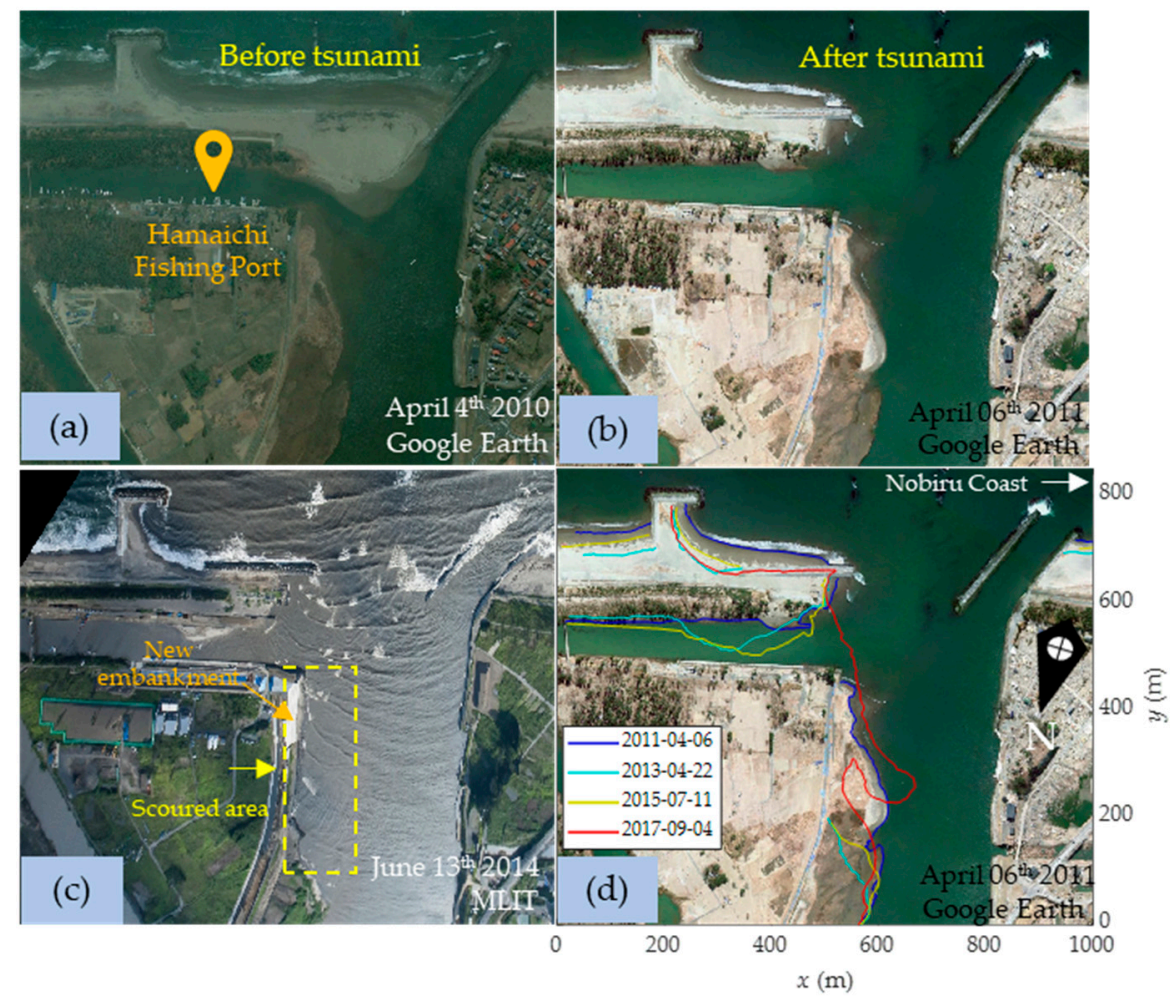

Figure 12. The Naruse River mouth. (a) Before the 2011 tsunami. (b) Disappearance of sandspit after the tsunami. (c) Scour inside the river mouth. (d) Sediment deposition inside the river mouth.
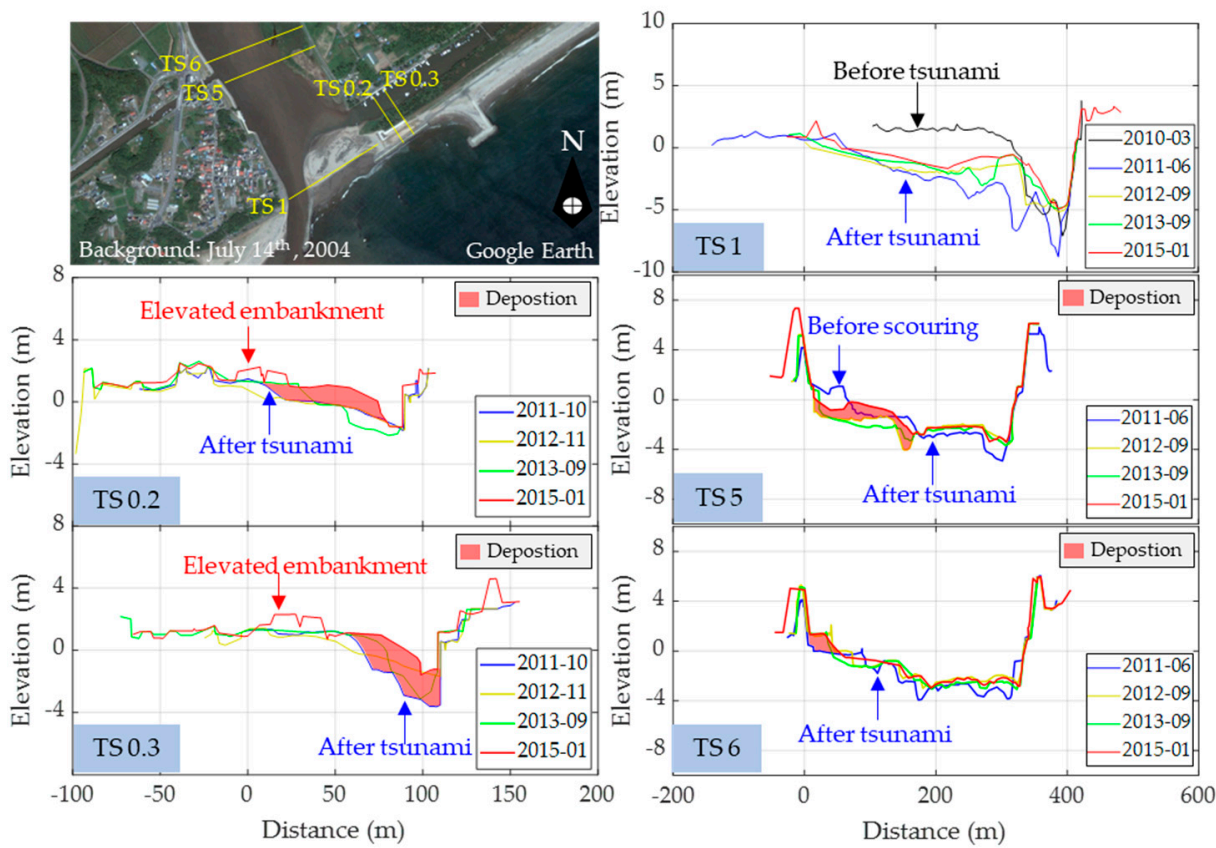

Figure 13. Deposited sediment in the Naruse River mouth after the tsunami (Datum: Tokyo Peil). 


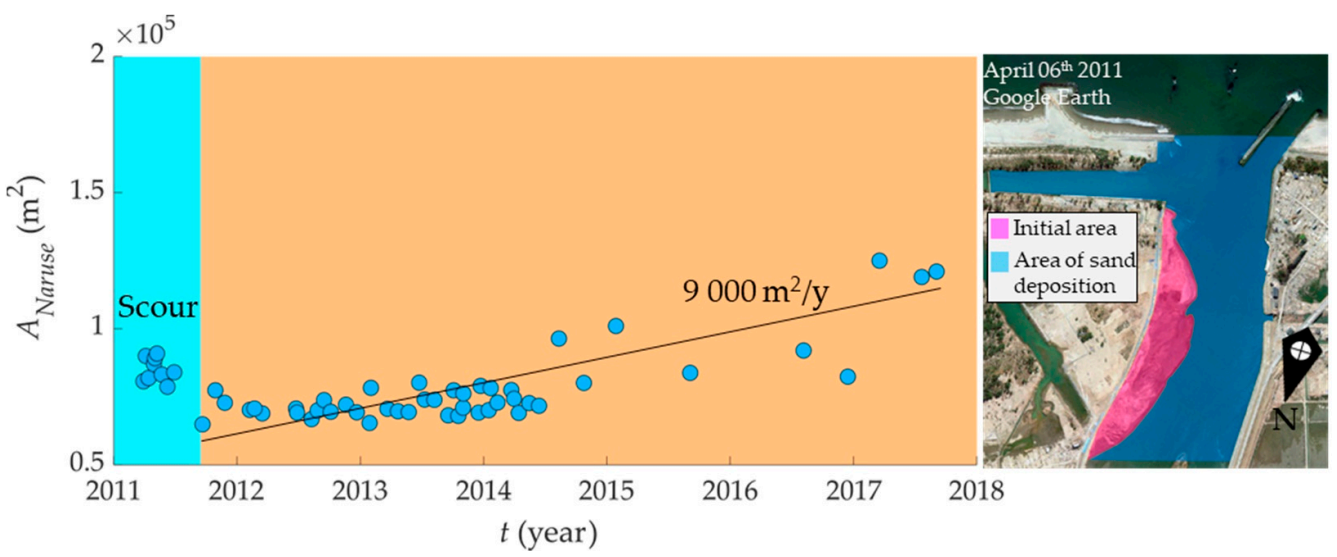

Figure 14. Measured area of sand deposition in the Naruse River mouth.

The deposit inside the river mouth is considered as a portion splitting from the annual sediment input to the Nobiru Coast and sinking into the mouth area. The volume of the deposited volume is almost equivalent to the deficit of annual net sediment input to the Nobiru Coast after the tsunami. Compared to many typical rivers, or wave- or tide-dominated river mouths in the world, the Naruse River mouth is considerably small and confined by structures (T-headlands and jetties) where the river discharge is relatively small [24] and important mouth features such as ebb-tidal deltas do not exist [23]. The sediment transport into the river caused by the tsunami is unfamiliar with earlier knowledge background. The absence of the sandspit until nowadays has led to an alteration to the long-term sediment budget in the Nobiru Coast in the future.

\subsection{Centennial to Decadal Sediment Budget at the Nobiru Coast and Future Management Implication}

The sediment budget calculations provided for 3 temporal periods are presented in Figure 15. The sediment budget shows good agreement on the sediment balance in each period and the residues are within the uncertainty range. The attention focuses on the sediment budget before and after the tsunami and the post-tsunami budget is highly important for the future coastal and river management of the Nobiru Coast and the Naruse River mouth owing to the ongoing problems. The first concern is about the future sediment deposition on the right end of the Nobiru Coast near the Katsugigaura Channel. As seen in Figure 8b, the severe deposition was observed before the tsunami and the connection between the Nobiru Coast and Miyato Island interrupted the sea water exchange in the Matsushima Bay. The closure affected the water quality and the aquaculture in the Matsushima Bay. The cut in the production of oysters which is one of the largest aquaculture productions in the Matsushima Bay made the government implement immediate dredging action in 2008 to clear the path between the coast and Miyato Island. With the new annual net sediment input to the Nobiru Coast and its deficit after the tsunami, the next closure is expected in about 25 30 years. The second concern is the sediment intrusion in the Naruse River mouth. In Figure 12a, the existence of the Hamaichi Fishing Port in the Kitakami Canal is noticed. The continuous sediment intruding into the canal influences the fishing activities of fishermen and causes an extreme danger for the traffic of boats and vessels due to the shallower water depth in the canal and mouth area. With the context of the sediment budget of the Nobiru Coast in the study, a long-term mitigation and suitable adaption planning is expected to be approached by the government authorities in the near future. 


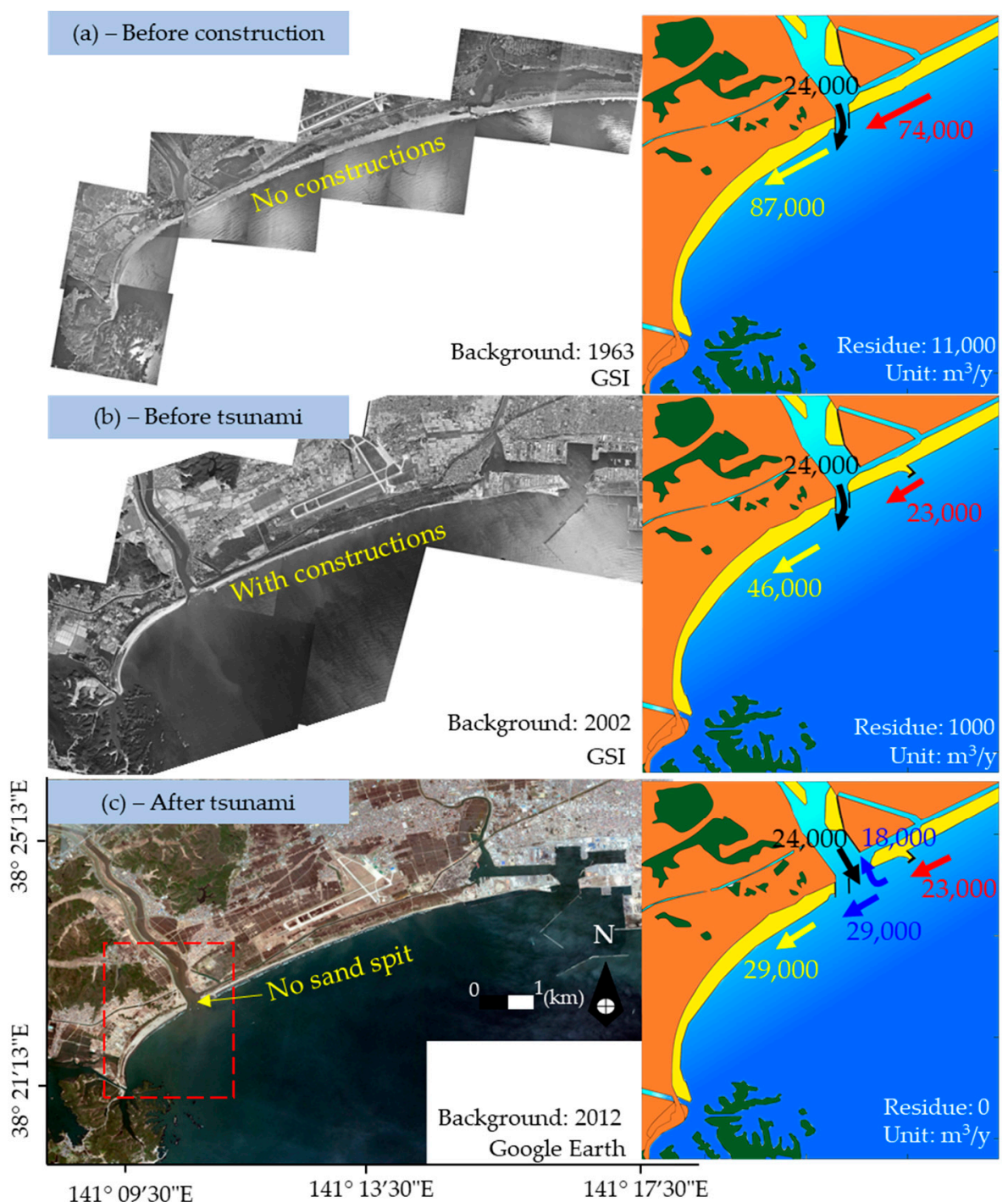

Figure 15. Centennial-to-decadal sediment budget in the Nobiru Coast. (a) Period 1: Before construction. (b) Period 2: Before the 2011 tsunami. (c) Period 3: After the 2011 tsunami.

\section{Conclusions}

The centennial-to-decadal morphology changes and annual net sediment input of the Nobiru Coast was investigated thoroughly by historical maps and images along with in situ beach surveys. The main findings are as follows.

From 1800 to 1981, the Nobiru coast was not under the impact of construction in Ohmagari Coast. The sediment deposited excessively with the annual net sediment input of $87,000 \mathrm{~m}^{3} / \mathrm{y}$. After the completion of the detached breakwaters and headlands, the deposition rate fell to $46,000 \mathrm{~m}^{3}$ /y. After the 2011 Great East Japan Earthquake and Tsunami, the annual net sediment input decreased to $29,000 \mathrm{~m}^{3} / \mathrm{y}$. The loss in sediment supply was a result of the sediment intrusion in the Naruse River mouth. During the recovery after the tsunami, the deposition rate inside the mouth area of Naruse River balanced the deficit of the Nobiru Coast. With the most recent sediment budget, this study is expected to support government authorities in making a long-term adaptive master plan for coastal and river management in this area in the future.

Author Contributions: N.T.H. collected and analyzed the images and field measurement data sets. H.T. led group discussions and checked the contents. N.X.T. made contributions in collecting the in situ beach surveys. All authors have read and agreed to the published version of the manuscript. 
Funding: This research was funded by the TAISEI Research Foundation.

Institutional Review Board Statement: Not applicable.

Informed Consent Statement: Not applicable.

Data Availability Statement: Data sets are contained within the article. Further data and materials requests should be addressed to nguyen.hiep.trong.p5@dc.tohoku.ac.jp (N.T.H.) or hitoshi.tanaka.b7@tohoku.ac.jp (H.T.).

Acknowledgments: This work was financially supported by the TAISEI Research Foundation. The authors would like to gratefully acknowledge all the supports from the Ministry of Land, Infrastructure, and Transport (MLIT) and Miyagi Prefectures for providing the valuable river water level data, in situ bathymetry data, and aerial photographs. In addition, we also personally thank Yoko Sato for providing the original of an old aerial image of the Nobiru Coast.

Conflicts of Interest: The authors declare no conflict of interest.

\section{References}

1. Liu, P.L.F.; Lynett, P.; Fernando, H.; Jaffe, B.E.; Fritz, H.; Higman, B.; Morton, R.; Goff, J.; Synolakis, C. Observations by the international tsunami survey team in SriLanka. Science 2005, 308, 1595. [CrossRef]

2. Borrero, J.C. Field survey of northern Sumatra and Banda Aceh, Indonesia after the tsunami and earthquake of 26 December 2004. Seismol. Res. Lett. 2005, 76, 312-320. [CrossRef]

3. Mori, N.; Takahashi, T.; Yasuda, T.; Yanagisawa, H. Survey of 2011 Tohoku earthquake tsunami inundation and run-up. Geophys. Res. Lett. 2011, 38. [CrossRef]

4. Fritz, H.M.; Petroff, C.M.; Catalán, P.A.; Cienfuegos, R.; Winckler, P.; Kalligeris, N.; Weiss, R.; Barrientos, S.E.; Meneses, G.; Valderas-Bermejo, C.; et al. Field survey of the 27 February 2010 Chile tsunami. Pure Appl. Geophys. 2011, 168, 1989-2010. [CrossRef]

5. Takahashi, T.; Shuto, N.; Imamura, F.; Asai, D. Modeling sediment transport due to tsunamis with exchange rate between bed load layer and suspended load layer. In Proceedings of the 27th International Conference on Coastal Engineering, Sydney, Australia, 16-21 July 2001; pp. 1508-1519.

6. Chavanich, S.; Siripong, A.; Sojisuporn, P.; Menasveta, P. Impact of tsunami on the 462 seafloor and corals in Thailand. Coral Reefs. 2005, 24, 535. [CrossRef]

7. Umitsu, M.; Tanavud, C.; Patanakanog, B. Effects of landforms on tsunami flow in the plains of Banda Aceh, Indonesia, and Nam Khem, Thailand. Mar. Geol. 2007, 242, 141-153. [CrossRef]

8. Pari, Y.; Ramana Murthy, M.V.; Jaya Kumar, S.; Subramanian, B.R.; Ramachandran, S. Morphological changes at Vellar estuary, India and impact of the December 2004 tsunami. J. Environ. Manag. 2008, 89, 45-57. [CrossRef] [PubMed]

9. Matsumoto, D.; Naruse, H.; Fujino, S.; Surphawajruksakul, A.; Jarupongsakul, T.; Sakakura, N.; Murayama, M. Truncated flame structures within a deposit of the Indian Ocean Tsunami: Evidence of syn-sedimentary deformation. Sedimentology 2008, 55, 1559-1570. [CrossRef]

10. Tanaka, H.; Tinh, N.X.; Umeda, M.; Hirao, R.; Pradjiko, E.; Mano, A.; Udo, K. Coastal and estuarine morphology changes induced by the 2011 Great East Japan earthquake tsunami. Coast. Eng. J. 2012, 54, 1250010. [CrossRef]

11. Suppasri, A.; Koshimura, S.; Imai, K.; Mas, E.; Gokon, H.; Muhari, A.; Imamura, F. Damage characteristic and field survey of the 2011 Great East Japan Tsunami in Miyagi Prefecture. Coast. Eng. J. 2012, 54, 1250010. [CrossRef]

12. Tappin, D.R.; Evans, H.M.; Jordan, C.J.; Richmond, B.; Sugawara, D.; Goto, K. Coastal changes in the Sendai area from the impact of 2011Tohoku-oki tsunami: Interpretations of time series satellite images, helicopter-borne video footage and field observation. Sediment. Geol. 2012, 282, 151-174. [CrossRef]

13. Udo, K.; Sugawara, D.; Tanaka, H.; Imai, K.; Mano, A. Impact of the 2011 Tohoku earthquake and tsunami on beach morphology along the northern Sendai Coast. Coast. Eng. J. 2012, 54, 1250009. [CrossRef]

14. Adityawan, M.B.; Dao, N.X.; Tanaka, H.; Mano, A.; Udo, K. Morphological changes along the Ishinomaki coast induced by the 2011 Great East Japan Tsunami and the relationship with coastal structures. Coast. Eng. J. 2014, 56, 1450016. [CrossRef]

15. Choowong, M.; Phantuwongraj, S.; Charoentitirat, T.; Chutakositkano, B.; Yumuang, S.; Charusiri, P. Beach recovery after 2004 Indian Ocean tsunami from Phang-Nga Thailand. Geomorphology 2009, 104, 134-142. [CrossRef]

16. Koiwa, N.; Takahashi, M.; Sugisawa, S.; Ito, A.; Matsumoto, H.; Tanavud, C.; Goto, K. Barrier spit recovery following the 2004 Indian Ocean tsunami at Pakarang Cape, southwest Thailand. Geomorphology 2017, 306, 314-324. [CrossRef]

17. Tanaka, H.; Adityawan, M.B.; Mano, A. Morphological changes at the Nanakita River mouth after the Great East Japan Tsunami of 2011. Coast. Eng. 2014, 86, 14-26. [CrossRef]

18. Roh, M.; Tanaka, H.; Mitobe, Y. Morphological characteristics of river mouths after the 2011 Tohoku Tsunami in Miyagi Prefecture. In Tsunamis and Earthquakes in Coastal Environments; Santiago-Fandino, V., Tanaka, H., Spiske, M., Eds.; Springer: Berlin/Heidelberg, Germany, 2016; pp. 137-152. 
19. Udo, K.; Tojo, K.; Takeda, Y.; Tanaka, H.; Mano, A. Characteristics of shoreline retreat due to the 2011 Tohoku Earthquake Tsunami and its recovery after three years. In Tsunamis and Earthquakes in Coastal Environments; Santiago-Fandino, V., Tanaka, H., Spiske, M., Eds.; Springer: Berlin/Heidelberg, Germany, 2016; pp. 113-123.

20. Tanaka, H.; Hiep, N.T. Decadal morphological recovery of estuaries and coasts after the 2011 Tohoku Tsunami. In Lecture Notes in Civil Engineering; Reddy, J., Wang, C., Luong, V., Le, A., Eds.; Springer: Berlin/Heidelberg, Germany, 2019; Volume 80, pp. 31-41.

21. Inoue, K.; Tanaka, H.; Izumi, N. Evaluation of long-term longshore sediment transport rate on Ishinomaki Coast. In Proceedings of the Coastal Engineering (JSCE), Kushiro, Japan, 23-25 October 2002; Volume 49, pp. 516-520. (In Japanese).

22. Takahashi, T.; Tanaka, H. Change in morphology and sediment budget in the vicinity of Ishinomaki Port. In Proceedings of the International Conference on Asian and Pacific Coast, Jeju, Korea, 4-8 September 2005; pp. 797-801.

23. Mochizuki, T.; Uda, T.; Ohrui, M.; Ohya, Y. Recent topography change on Sendai Bay. In Proceedings of the Coastal Engineering (JSCE), Hachinohe, Japan, 13-15 November 1990; Volume 37, pp. 369-373. (In Japanese).

24. Sato, S.; Yamamoto, K.; Wada, K.; Izawa, T.; Otani, Y.; Hashimoto, S. Observation of longshore sediment transport around headlands in the Omagari Coast and prediction of beach changes. In Proceedings of the Coastal Engineering (JSCE), Akita, Japan, 13-15 November 1998; Volume 45, pp. 556-560. (In Japanese).

25. Haraguchi, T.; Iwamatsu, A. Detailed Maps of the Impacts of the 2011 Japan Tsunami; Kokonshoin: Tokyo, Japan, 2011. (In Japanese)

26. Tanaka, H.; Kayane, K.; Adityawan, M.B.; Roh, M.; Farid, M. Study on the relation of river morphology and tsunami propagation in rivers. Ocean Dyn. 2014, 64, 1319-1332. [CrossRef]

27. Tolkova, E.; Tanaka, H.; Roh, M. Tsunami observations in rivers from a perspective of tsunami interaction with tide and riverine flow. Pure Appl. Geophys. 2015, 172, 953-968. [CrossRef]

28. Tanaka, H.; Tinh, N.X.; Hiep, N.T.; Kayane, K.; Roh, M.; Umeda, M.; Sasaki, M.; Kawagoe, S.; Tsuchiya, M. Intrusion distance and flow discharge in rivers during the 2011 Tohoku Tsunami. J. Mar. Sci. Eng. 2020, 8, 882. [CrossRef]

29. Tanaka, H.; Takahashi, G.; Matsutomi, H.; Izumi, N. Application of old maps for studying long-term shoreline change. In Proceedings of the 30th International Conference on Coastal Engineering, San Diego, CA, USA, 3-8 September 2006; pp. $4022-4534$.

30. Tanaka, H.; Matsutomi, H.; Izumi, N. Analysis of historical shoreline change in Miyagi and Fukushima Prefecture, Japan In Proceedings of the International Conference on Asian and Pacific Coasts, Jeju, Korea, 4-8 September 2005; pp. 797-801.

31. Iwamoto, K.; Hein, C.M. Cross-Cultural Engineering: The role of Dutch civil engineering in modern port planning in Japan (1870s-1890s). In Proceedings of the 18th International Planning History Society Conference, Yokohama, Japan, 15-19 July 2018; pp. 2468-6956.

32. Boak, E.; Turner, I. Shoreline Definition and Detection: A Review. J. Coast. Res. 2005, 21, 688-703. [CrossRef]

33. Everitt, B.S.; Landau, S.; Leese, M.; Stahl, D. Cluster Analysis, 5th ed.; Wiley: Hoboken, NJ, USA, 2011; p. 330.

34. Hennig, C.; Meila, M.; Murtagh, F.; Rocci, R. Handbook of Cluster Analysis, 1st ed.; Chapman and Hall/CRC: New York, NY, USA, 2015; p. 753.

35. Burningham, H.; French, J. Understanding coastal change using shoreline trend analysis supported by cluster-based segmentation. Geomorphology 2017, 282, 131-149. [CrossRef]

36. Otsu, N. A threshold selection method from gray-level histograms. IEEE Trans. Syst. Man Cybern. Syst. 1979, 20, 62-66. [CrossRef]

37. Valiente, N.G.; Masselink, G.; Scott, T.; Conley, D.; McCarroll, R.J. Role of waves and tides on depth of closure and potential for headland bypassing. Mar. Geol. 2019, 407, 60-75. [CrossRef]

38. Anthony, E.J.; Aagaard, T. The lower shoreface: Morphodynamics and sediment connectivity with the upper shoreface and beach. Earth Sci. Rev. 2020, 210, 103334. [CrossRef]

39. Stive, M.J.F.; de Vriend, H.J.; Nicholls, R.J.; Capobianco, M. Shore nourishment and the active zone: A time scale dependent view. In Proceedings of the 23th International Conference, Venice, Italy, 4-9 October 1992; pp. 2464-2473.

40. Stive, M.J.F.; Roelvink, D.A.; de Vriend, H.J. Large-scale coastal evolution concept. The Dutch Coast, Paper No. 9. In Proceedings of the 22nd International Conference on Coastal Engineering, Delft, The Netherlands, 2-6 July 1990; p. 13.

41. Stive, M.J.F.; de Vriend, H.J. Modeling shoreface profile evolution. Mar. Geol. 1995, 126, 235-248. [CrossRef]

42. Sabatier, F.; Stive, M.J.F.; Pons, F. Longshore variation of depth of closure on a micro-tidal wave-dominated coast. In Proceedings of the 29th International Conference, National Civil Engineering Laboratory, Lisbon, Portugal, 19-24 September 2004; pp. 2327-2339.

43. Hinton, C.; Nicholls, R.J. Spatial and temporal behavior of depth of closure along the Holland coast. In Proceedings of the 26th International Conference on Coastal Engineering, Copenhagen, Denmark, 22-26 June 1998; pp. 2913-2925.

44. Sato, Y. Air Travel in Taisho and Early Showa Period: CHOJINKI (Archives of a Birdman) in Sendai and Miyagi; Seiado: Sendai, Japan, 2019; p. 127. (In Japanese)

45. Dao, N.X.; Adityawan, M.B.; Tanaka, H.; Sundar, V. Sensitivity analysis of relationship between tsunami disaster and coastal embankment structure. J. JSCE (Hydraulic Eng.) 2014, 58, 43-48. [CrossRef]

46. Uda, T. Beach Erosion in Japan; Sankaido Press: Tokyo, Japan, 1997; p. 242. (In Japanese)

47. Widyaningtia, H.T.; Kanayama, S. Depth of closure determination in the vicinity of coastal structure. In Proceedings of the 33rd International Conference on Coastal Engineering, Santander, Spain, 1-6 July 2012; p. 15.

48. Pelnard-Considere, R. Essai de Theorie de l'Evolutio des Form de Rivage en Plage de Sable et de Galets. In Proceedings of the 4th Journees de l'Hydaulique, Les Energies de la Mer, Question III, La Houille Blanche, Grenoble, France, 13-15 June 1956; Volume 1, pp. 289-298. 
49. Rosati, J.D.; Kraus, N.C. Formulation of Sediment Budgets at Inlets. Coastal Engineering Technical Notes CETN IV-15, Vicksburg, Mississippi: Coastal Inlets Research Program; US Army Corps of Engineers: Washington, DC, USA, 1998; p. 16.

50. Hiep, N.T.; Tanaka, H.; Tinh, N.X. Post-tsunami recovery and morphology change at Naruse River mouth, Japan. In Proceedings of the 10th International Conference on Asian and Pacific Coasts, Hanoi, Vietnam, 25-28 September 2019; pp. 797-801. 